\title{
Water distribution in quartz schists of the Sanbagawa Metamorphic Belt, Japan: infrared spectroscopic mapping and comparison of the calibrations proposed for determining water contents
}

\author{
Jun-ichi Fukuda ${ }^{1,2,3^{*}}$ and Ichiko Shimizu ${ }^{1,4}$ (i)
}

\begin{abstract}
We evaluated water distributions in deformed quartz in schists along the Asemi River, Central Shikoku, in the Sanbagawa Metamorphic Belt, Japan, using infrared spectroscopic (IR) mapping. The water trapped in quartz as molecular $\mathrm{H}_{2} \mathrm{O}$ showed a broad IR absorption band at $2800-3750 \mathrm{~cm}^{-1}$. A necessary step before assessing the quartz water content was to evaluate and compare six previously proposed IR calibrations in terms of the molar absorption coefficients of $\mathrm{H}_{2} \mathrm{O}\left(\mathrm{L} / \mathrm{mol} \mathrm{H}_{2} \mathrm{O} \mathrm{cm}\right)^{2}$. The coefficients vary from 24,100 to $89,000 \mathrm{~L} / \mathrm{mol} \mathrm{H}_{2} \mathrm{O} \mathrm{cm}{ }^{2}$, and the values of the coefficients show a rough increase with increasing component of structural $-\mathrm{OH}$ in the IR spectra. We used Paterson's calibration, which does not require input regarding the mineral species, but which was modified in his paper for measurements of molecular $\mathrm{H}_{2} \mathrm{O}$ in quartz. The absorption coefficient is $38,000 \mathrm{~L} / \mathrm{mol} \mathrm{H}_{2} \mathrm{O} \mathrm{cm}{ }^{2}$. IR mapping was performed on Sanbagawa metamorphic rocks with increasing grades of metamorphism, where the mean grain size of quartz increases from $\sim 40$ to $\sim 120 \mu \mathrm{m}$. The absorption bands that are only from the quartz can be distinguished on the basis of microstructural observations and the corresponding mapping results. The IR spectra of quartz commonly show dominant molecular $\mathrm{H}_{2} \mathrm{O}$ bands at $2800-3750 \mathrm{~cm}^{-1}$ with no additional bands associated with crystalline $-\mathrm{OH}$ when only quartz is measured. The water contents of quartz in all our samples were 40-310 ppm, and these values are about one-third of previously reported values measured using point analyses with the unified Paterson's calibration. This difference seems to reflect the incorporation of phyllosilicates in previous measurements that showed a broad band around $3600 \mathrm{~cm}^{-1}$. The lowest and highest water contents in our quartz samples are associated with intragranular water and grain boundary water, respectively. We estimated the grain boundary widths to be at most $\sim 10 \mathrm{~nm}$ on the basis of the water contents at grain boundaries.
\end{abstract}

Keywords: Quartz, Water content, Infrared spectroscopy, Calibration, Sanbagawa Metamorphic Belt

\section{Introduction}

Quartz is widespread in the Earth's crust and is a control on rheology. It is well known that water affects the plastic deformation of quartz, as confirmed by many experimental works (e.g., Griggs and Blacic 1965; Griggs

\footnotetext{
*Correspondence: jfukuda@crystal.kobe-u.ac.jp

${ }^{3}$ Present Address: Research Center for Inland Seas, Kobe University, 1-1

Rokkodai-cho, Nada-ku, Kobe, Hyogo 657-8501, Japan

Full list of author information is available at the end of the article
}

1967; Parrish et al. 1976; Jaoul et al. 1984; Kronenberg and Tullis 1984; Koch et al. 1989; Post et al. 1996; Chernak et al. 2009; Holyoke and Kronenberg 2013; Fukuda et al. 2018) and theoretical models (Fukuda and Shimizu 2017). However, the quantitative relationship between water content and the plastic deformation of quartz has not been established, even though a rough link between the plastic weakness of quartz and water content is well known. In addition to studies of quartz in deformation 
experiments, the water contents of naturally deformed quartz have also been measured (Kronenberg and Wolf 1990; Kronenberg et al. 1990; Kronenberg 1994; Nakashima et al. 1995; Niimi et al. 1999; Muto et al. 2004, 2005; Gleason and DeSisto 2008; Menegon et al. 2011; Fukuda 2012; Finch et al. 2016; Kilian et al. 2016; Kronenberg et al. 2017), although it is still difficult to relate the measured water content to the development of plastic deformation in nature. To measure the water contents in quartz and to assess the nature of the water species (i.e., as molecular $\mathrm{H}_{2} \mathrm{O}$ or $-\mathrm{OH}$ coupled with cations), infrared (IR) spectroscopy is used. IR mapping measurements can be correlated with the textures of the sample, and they are useful for evaluating the distribution of water in the area of analysis (e.g., Ito and Nakashima 2002; Fukuda 2012; Fukuda et al. 2012; Kronenberg et al. 2017).

In this paper we present the results of IR mapping measurements to show how water is distributed in and around deformed quartz in the Sanbagawa (or Sambagawa) Metamorphic Belt along the Asemi River in Shikoku, Japan, where the deformed quartz represents a variety of metamorphic conditions. The water contents in quartz aggregates in this area were also measured by Nakashima et al. (1995), who developed an IR calibration to determine the water contents in the quartz, and here we will compare their scheme with other calibrations. Nakashima et al. (1995) also performed point IR analyses, but information on the textures of the samples was not linked to the IR results. In this paper we discuss sample textures and water contents measured by IR mapping. We summarize various IR calibrations that have been proposed, and we compare them in terms of the absorption coefficients using the same unit $\left(\mathrm{L} / \mathrm{mol} \mathrm{H}_{2} \mathrm{O} \mathrm{cm}{ }^{2}\right)$.

\section{Samples}

Deformed metasedimentary rocks from the Sanbagawa Metamorphic Belt were collected along the Asemi River in Shikoku, Japan. The samples increase in metamorphic grade from the chlorite to the biotite zone along the river from south to north (e.g., Banno et al. 1978; Itaya 1981; Higashino 1990). Enami et al. (1994) estimated the pressures and temperatures of the chlorite, garnet, and biotite zones in this region to have been 5.5-6.5 kbar and $<360{ }^{\circ} \mathrm{C}, 7.0-8.5 \mathrm{kbar}$ and $440 \pm 15^{\circ} \mathrm{C}$, and 8.0-9.5 kbar and $520 \pm 25{ }^{\circ} \mathrm{C}$, respectively. Higashino (1990) further divided the biotite zone into albite-biotite and oligoclase-biotite zones (Fig. 1).

For our study, three rock types (siliceous, pelitic, and psammitic schists) were used for the IR analyses. Figure 2 shows examples of their textures in samples from the three metamorphic zones (No. 7-93, chlorite zone; No. 7-45, garnet zone; and No. 7-26, oligoclase-biotite zone). Each sample was cut parallel to the lineation and

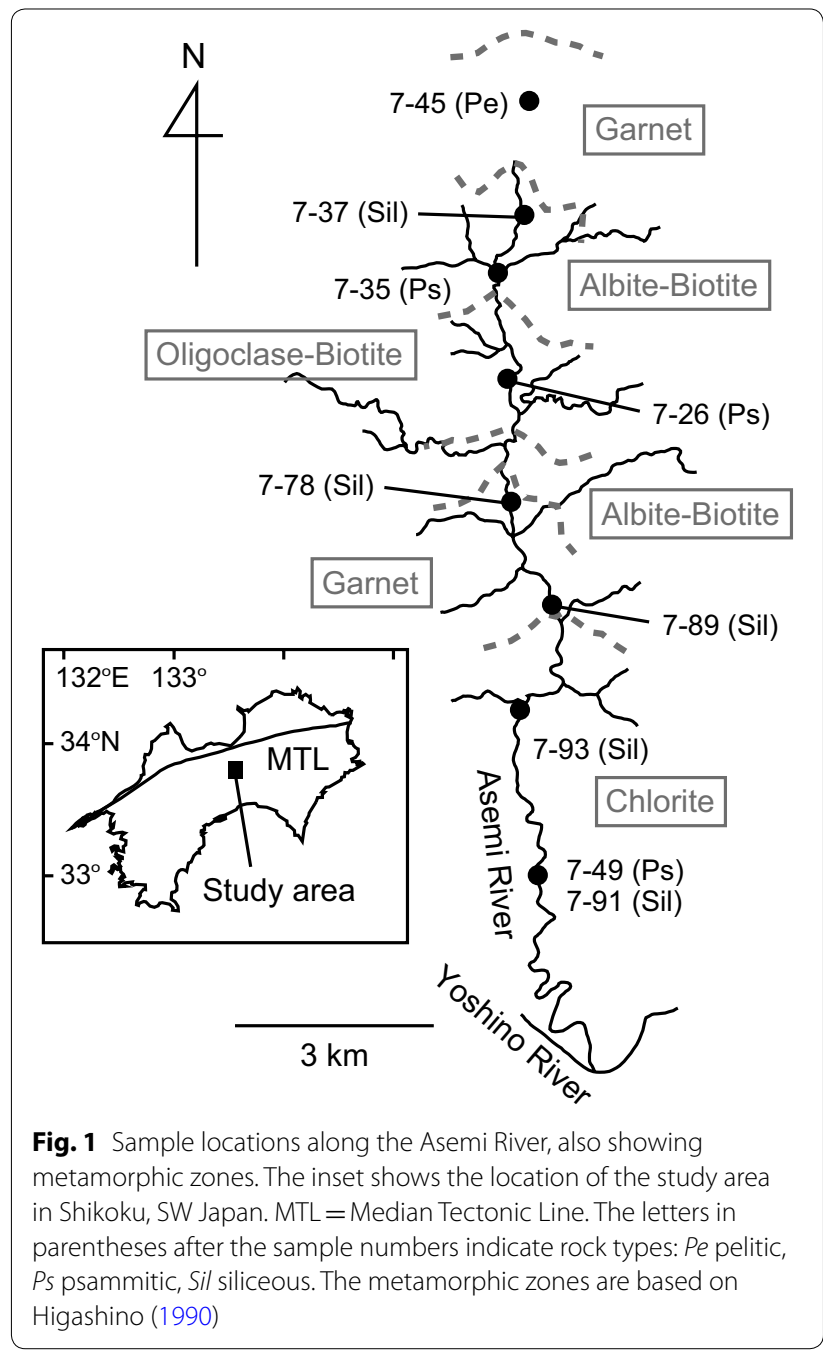

perpendicular to the foliation (i.e., $\mathrm{XZ}$ sections). The samples consist mainly of layers of quartz and albite (or oligoclase) along with patches of phyllosilicate minerals such as muscovite and chlorite, with biotite also present in the highest grade zone. The phyllosilicates are sometimes concentrated in layers, and porphyroblasts of albite are locally present. The accessory minerals include hematite, garnet, piemontite, calcite, and apatite. Relic detrital grains of feldspar and quartz form porphyroclasts in the psammitic schist samples of the chlorite zone.

Tagami and Takeshita (1998) and Yagi and Takeshita (2002) reported type-I and type-II cross-girdles (Lister 1977) for quartz $c$-axes fabrics in this area. Yagi and Takeshita (2002) measured the grain sizes of quartz as the diameters of circles equivalent to the areas of the approximately elliptical grains. They reported an increase in the average grain size of the recrystallized quartz from $\sim 20$ to $\sim 180 \mu \mathrm{m}$ with increasing metamorphic grade. 

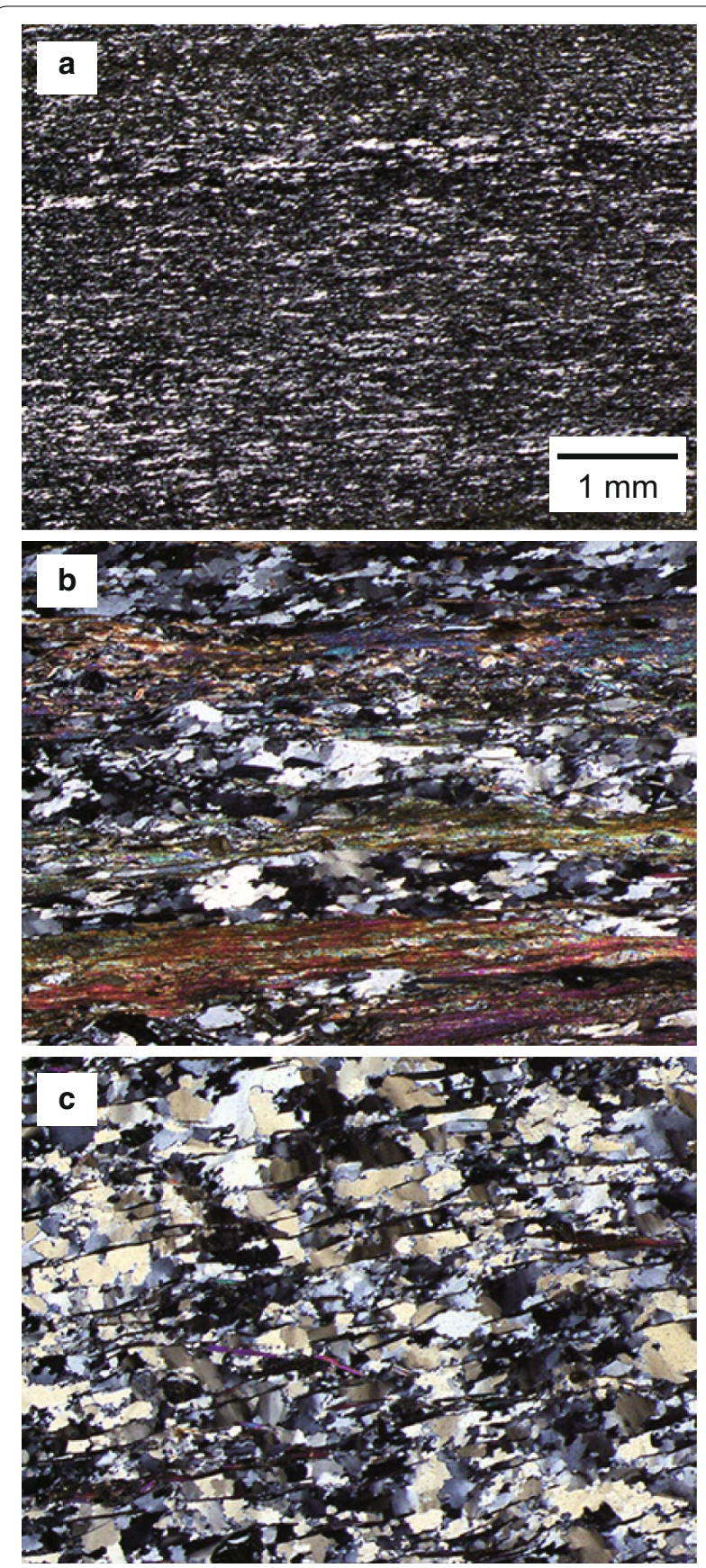

Fig. 2 Optical photomicrographs of the metamorphic rock specimens from different metamorphic zones (cross-polarized light). See Fig. 1 for the locations. a Sample No. 7-93 (chlorite zone). b Sample No. 7-45 (garnet zone). c Sample No. 7-26 (oligoclase-biotite zone). The scale is the same in all images

Masuda (1982) classified grain morphologies of recrystallized quartz along the Asemi River route into P- and $\mathrm{S}$-types, which were originally defined for experimentally deformed and recrystallized samples by Masuda and Fujimura (1981). Yagi and Takeshita (2002) categorized the recrystallized microstructures of quartz as type-I, type-II, or type-III, following the definitions of Hara et al. (1988, 1992). The type-I quartz microstructure is characterized by highly elongate quartz grains with aspect ratios of $\geq 4.0$ that display undulatory extinction as well as subgrain formation in and around the host grains, and type-I corresponds to the S-type microstructure of Masuda and Fujimura (1981). The type-II microstructure is characterized by quartz grains that have aspect ratios of $\leq 4.0$, grain boundaries that are straight or lobate, and no clear relationships between the host grains and subgrains, and type-II corresponds to the P-type microstructure of Masuda and Fujimura (1981). The type-III microstructure is characterized by quartz grains that have a shape fabric that is oblique to the foliation defined by the alignment of phyllosilicates. Based on these definitions, the quartz microstructures of our samples (Fig. 2) can be classified into type-I or type-II (No. 7-93), type-II or type-III (No. 7-45), and type-III (No. 7-26). The average grain sizes of the quartz, using the method of Yagi and Takeshita (2002), range from $\sim 40$ to $\sim 120 \mu \mathrm{m}$.

\section{Analytical methods}

We measured the IR spectra of the quartz in our schist samples, together with the spectra of other minerals for comparison, and we focused on the distributions of water. We also prepared a specimen of chalcedony from Oshamanbe, Hokkaido, Japan, as this material contains large amounts of molecular $\mathrm{H}_{2} \mathrm{O}$ (Fukuda and Nakashima 2008; Fukuda et al. 2009a, b). The IR spectra were measured at room temperature using a Fourier transform IR microspectrometer (JASCO IRT-3000) equipped with an autosample stage (IPS-3000) and a mercury-cadmiumtelluride detector. Unpolarized IR light comes through the main spectrometer (FT/IR-6100) equipped with a silicon-carbide IR source and $\mathrm{CaF}_{2}$ beamsplitter. The aperture size was either $30 \times 30 \mu \mathrm{m}$ or $50 \times 50 \mu \mathrm{m}$, and the same step distances were applied during the mapping measurements. The spectral resolution was $4 \mathrm{~cm}^{-1}$, and each spectrum was averaged from 128 scans. The thicknesses of the $\mathrm{XZ}$ section samples, measured with a micrometer, were in the range $80-120 \pm 5 \mu \mathrm{m}$, which was suitable for both textural observations and good IR signals. Before the IR measurements, the samples were heated to $\sim 120{ }^{\circ} \mathrm{C}$ for $\sim 1 \mathrm{~h}$ to remove molecular $\mathrm{H}_{2} \mathrm{O}$ from open pores. The mapping measurements were taken on areas that included quartz and phyllosilicates previously observed under a polarizing microscope and then a microscope equipped with the IR microspectrometer. These visible minerals can therefore be taken as marker locations to help interpret the spectral contrasts in the mapping results. The IR spectra were normalized to 1-cm sample thicknesses. Integral absorbances and band 
heights of water stretching bands in the range of 2850$3750 \mathrm{~cm}^{-1}$ were determined using linear baselines in the same region. The linear baseline correction is based on an assumption that scattering and absorption of IR linearly depend on wave number by many possible factors such as sample color, grain size, and the focus and refraction of the IR passing through the optical system: For example, when light enters the sample, a wave of shorter wavelength scatters more at the surface of the sample than a wave of longer wavelength. It then undergoes wavelength-dependent refraction as it passes through the sample, and then leaves the sample. As a consequence, the absorbance increases linearly with progressively shorter wavelengths (i.e., higher wave numbers).

\section{Differences among the IR calibrations}

We compare six previously reported IR calibrations for determining water contents. In IR spectra, the $\mathrm{OH}$ fundamental stretching vibrations, seen at wave numbers of $2800-3750 \mathrm{~cm}^{-1}$, are often used, and combination bands and overtone bands are also sometimes used. The BeerLambert law can then be used to convert absorbance to concentration, as follows:

$$
A_{\mathrm{h}}=\varepsilon_{\mathrm{h}} c t
$$

where $A_{\mathrm{h}}$ is the band height at a specific wave number, $\varepsilon_{\mathrm{h}}$ is the absorption coefficient, $c$ is the concentration, and $t$ is the thickness. Instead of band height, integral absorbance is often used, as follows:

$$
A_{\text {int }}=\varepsilon_{\text {int }} c t
$$

where $A_{\text {int }}$ is the integral absorbance and $\varepsilon_{\text {int }}$ is the absorption coefficient.

Many calibrations have been proposed to determine the water content in quartz using IR spectroscopy (Kats 1962; Paterson 1982; Aines et al. 1984; Nakashima et al. 1995; Libowitzky and Rossman 1997; Stipp et al. 2006; Thomas et al. 2009), and they have been discussed recently in connection with studies concerning the crystallographic orientations of quartz and the orientations of irradiated polarized IR light (e.g., Stalder and Konzett 2012; Baron et al. 2015; Frigo et al. 2016). The calibrations of Paterson (1982) and Libowitzky and Rossman (1997) do not require information on the mineral species, and they assume that the absorption coefficients increase linearly with wave number. The other calibrations listed above were determined specifically for quartz. Each proposed calibration uses different units such as absorption coefficients of $\mathrm{L} / \mathrm{mol} \mathrm{H} \mathrm{cm}{ }^{2}$ or $\mathrm{L} / \mathrm{mol}_{2} \mathrm{O} \mathrm{cm}{ }^{2} \mathrm{ppm}$ where the former is converted to the latter by multiplying by two, or simplified equations with factors that include specific sample thickness, quartz density, etc. The calculated water contents are also given variously as ppm $\mathrm{H} / \mathrm{Si}$ or ppm $\mathrm{H}_{2} \mathrm{O}$. It is difficult, therefore, to see how the use of such a varied mix of calibration methods can provide reliable and consistent values of water contents. The differences in the results that arise from the use of different calibrations have seldom been discussed or reported in the literature, and each author has seemingly chosen a particular calibration on an ad hoc basis. However, exceptions are Stipp et al. (2006) and Kilian et al. (2016), who compared the water contents calculated with different calibrations.

In this paper, we express the water contents in the quartz as wt ppm $\mathrm{H}_{2} \mathrm{O}$, and the obtained values of integral absorbance and absorption coefficients, given as $\mathrm{L} /$ mol $\mathrm{H}_{2} \mathrm{O} \mathrm{cm}$, are converted to wt ppm $\mathrm{H}_{2} \mathrm{O}$ as follows:

$$
\text { wt ppm } \mathrm{H}_{2} \mathrm{O}=\frac{M_{\mathrm{H}_{2} \mathrm{O}} A_{\text {int }}}{t \rho \varepsilon_{\text {int }}} \times 10^{6}
$$

where $M_{\mathrm{H}_{2} \mathrm{O}}$ is the molar mass of $\mathrm{H}_{2} \mathrm{O}(18 \mathrm{~g} / \mathrm{mol}), A_{\text {int }}$ is the integral absorbance, $t$ is the sample thickness in centimeters, $\rho$ is the density of quartz $(2650 \mathrm{~g} / \mathrm{L})$, and $\varepsilon_{\text {int }}$ is in $\mathrm{L} / \mathrm{mol} \mathrm{H}_{2} \mathrm{O} \mathrm{cm}{ }^{2}$. By using $M_{\mathrm{H}_{2} \mathrm{O}}$ and the molar mass of $\mathrm{SiO}_{2}, 1$ wt ppm $\mathrm{H}_{2} \mathrm{O}$ converts to $6.67 \mathrm{ppm} \mathrm{H} / \mathrm{Si}$. The calibrations we compare are given in Table 1 in terms of the same unified unit, which is an integral absorption coefficient $\left(\mathrm{L} / \mathrm{mol} \mathrm{H}_{2} \mathrm{O} \mathrm{cm}{ }^{2}\right)$. Some of the original calibrations are given in different units and/or expressions. We describe below the procedures we used for making comparisons and give a unified unit.

The calibrations of Kats (1962) and Aines et al. (1984) use factors related to integral absorbance to calculate the water content in ppm H/Si. Using Eq. (3), their calibrations gave the equivalent absorption coefficients of 55,800 and $43,100 \mathrm{~L} / \mathrm{mol} \mathrm{H}_{2} \mathrm{O} \mathrm{cm}^{2}$, respectively (Table 1).

Nakashima et al. (1995) measured the IR spectra of water in Brazilian agate and in the recrystallized quartz grains of the Sanbagawa metamorphic rocks from the same locations we sampled along the Asemi River. They showed that the water stretching bands could be attributed mainly to molecular $\mathrm{H}_{2} \mathrm{O}$. In their water content calculations, they used maximum band heights around $3400 \mathrm{~cm}^{-1}$, the absorption coefficient of $81 \mathrm{~L} / \mathrm{mol} \mathrm{cm}$ for liquid water given by Thompson (1965), $M_{\mathrm{H}_{2} \mathrm{O}}$, and the density of quartz. As a result, they obtained the calibration shown by Eq. (1) (Table 1). To compare the calibration of Nakashima et al. (1995), which uses band heights, with the other calibrations that use integral absorbances (Kats 1962; Paterson 1982; Aines et al. 1984; Libowitzky and Rossman 1997; Stipp et al. 2006; Thomas et al. 2009), we quantitatively related integral absorbances to band heights in the regions of the water fundamental stretching vibrations. The IR spectra in Fig. 3a show different integral absorbances at $2800-3750 \mathrm{~cm}^{-1}$ and band heights around $3400 \mathrm{~cm}^{-1}$ for quartz and feldspar from 
Table 1 List of proposed calibrations

\begin{tabular}{|c|c|c|c|}
\hline Study & Equation & $\varepsilon_{\text {int }}\left[\mathrm{L} / \mathrm{mol} \mathrm{H}_{2} \mathrm{O} \mathrm{\textrm {cm } ^ { 2 } ]}\right.$ & Ratio of $c$ \\
\hline Kats (1962) & $c=0.812 \cdot A_{\text {int }} / t[p p m ~ H / S i]$ & 55,800 & 0.68 \\
\hline Aines et al. (1984) & $c=1.05 \cdot A_{\text {int }} / t[p p m ~ H / S i]$ & 43,100 & 0.88 \\
\hline Nakashima et al. (1995) & $c=84 \cdot A_{h} / t[w t p p m]$ & $33,200^{\mathrm{a}}$ & 1.15 \\
\hline Paterson (1982) & $\varepsilon_{\text {int eff }}=A_{\text {int }} / c \cdot t\left[\mathrm{~L} / \mathrm{mol} \mathrm{H}_{2} \mathrm{O} \mathrm{cm}{ }^{2}\right]$ & $38,000^{b}$ & 1.00 \\
\hline Paterson (1982) simplified ${ }^{c}$ & $\varepsilon_{\text {int }}=150 \cdot \gamma \cdot\left(3780-v_{\text {mean }}\right)\left[\mathrm{L} / \mathrm{mol} \mathrm{H} \mathrm{cm}{ }^{2}\right]$ & $38,000\left(v_{\text {mean }}=3400, \gamma=1 / 3\right)$ & 1.00 \\
\hline Libowitzky and Rossman (1997) & $\varepsilon_{\text {int }}=246.6 \cdot \gamma \cdot\left(3753-v_{\text {mean }}\right)\left[\mathrm{L} / \mathrm{mol} \mathrm{H}_{2} \mathrm{O} \mathrm{cm}{ }^{2}\right]$ & $29,000\left(v_{\text {mean }}=3400, \gamma=1 / 3\right)$ & 1.31 \\
\hline Stipp et al. (2006) & $C=100 \cdot M \cdot A_{\text {int }} /\left(t \cdot \rho \cdot \varepsilon_{\text {int }}\right)\left[w t \% \mathrm{H}_{2} \mathrm{O}\right]$ & 24,100 & 1.58 \\
\hline Thomas et al. (2009) & $c=A_{\text {int }} / \varepsilon_{\text {int }} \cdot t\left[w t \% \mathrm{H}_{2} \mathrm{O}\right]$ & 89,000 & 0.43 \\
\hline
\end{tabular}

The equations given are the originals from each paper. The unit referred to on the left side of each equation is given in brackets

a The absorption coefficient of Nakashima et al. (1995) using band heights was converted to a coefficient for integral absorbance using Eq. (4)

b The water content $c$ was determined using Eq. (5)

c This follows the method of Libowitzky and Rossman (1997) and was used for the IR mapping data. See the text for further details
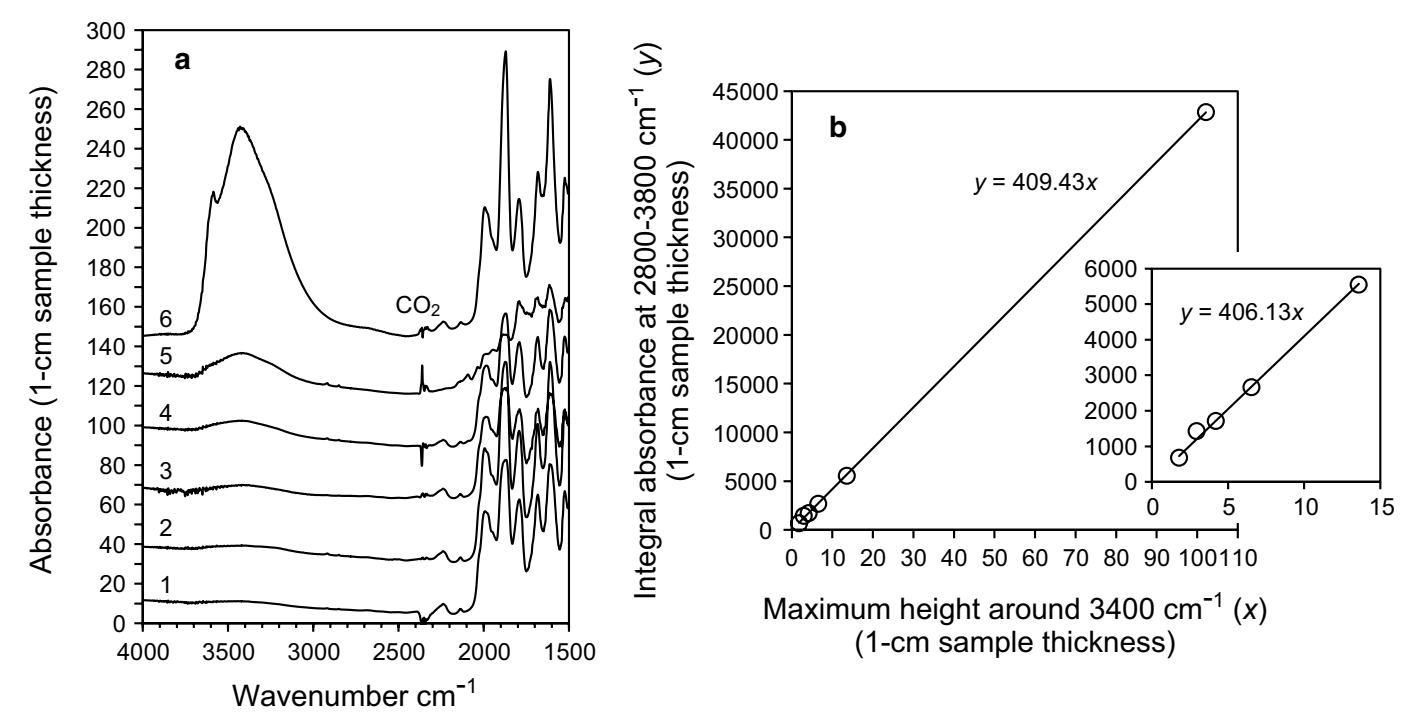

Fig. 3 a IR spectra showing different absorbances of water bands at $2800-3750 \mathrm{~cm}^{-1}$. Spectra numbers: 1-4= quartz from the Asemi River, with $1=$ sample No. 7-35, $2=$ No. 7-49, 3=No. 7-89, and 4=No. 7-35 (healed cracks; see the IR mapping result in Fig. 8 and the text); $5=$ albite porphyroblast with minor quartz (No. 7-35); $6=$ chalcedony from Oshamanbe. The structural vibrations $<2300 \mathrm{~cm}^{-1}$ roughly distinguish mineral species. The spectra show typical stretching bands of molecular $\mathrm{H}_{2} \mathrm{O}$. Atmospheric $\mathrm{CO}_{2}$ bands are seen around $2360 \mathrm{~cm}^{-1}$. The IR spectrum of chalcedony has a weak Si-OH band at $3585 \mathrm{~cm}^{-1}$. b Relationship between band heights and integral absorbance of molecular $\mathrm{H}_{2} \mathrm{O}$. The left figure includes data for chalcedony that show much higher values than the others. The right figure shows only data for the Asemi River samples

the Asemi River and chalcedony. The spectra commonly show broad bands due to molecular $\mathrm{H}_{2} \mathrm{O}$. The IR spectra for the chalcedony show a much higher absorbance than in the other samples. They also include a weak $\mathrm{Si}-\mathrm{OH}$ band at $3585 \mathrm{~cm}^{-1}$, which is typical of chalcedony and agate and associated with dislocation $\mathrm{Si}-\mathrm{OH}$ and surface $\mathrm{Si}-\mathrm{OH}$ at grain boundaries because of fine grains (e.g., a few hundred nanometers) (e.g., Flörke et al. 1982; Frondel 1982; Graetsch et al. 1985; Nakashima et al. 1995). The contribution of this band to the integral absorbance is not significant. The maximum band heights around $3400 \mathrm{~cm}^{-1}$ and the integral absorbances at 2800 $3750 \mathrm{~cm}^{-1}$ show a good correlation (Fig. 3b), regardless of whether the data include or exclude chalcedony. The trend shown in Fig. 3b is valid, since the feature of molecular $\mathrm{H}_{2} \mathrm{O}$ should be preserved for any materials that show clear molecular $\mathrm{H}_{2} \mathrm{O}$ bands. According to the slope in Fig. 3b, the relationship between band height and integral absorbance can be simplified as follows:

$$
A_{\text {int at } 2800-3750 \mathrm{~cm}^{-1}}=410 \times A_{\mathrm{h} \text { at } \sim 3400 \mathrm{~cm}^{-1}}
$$


Using this relationship and Eq. (3), the integral absorption coefficient converted from the original calibration of Nakashima et al. (1995) is $33,200 \mathrm{~L} / \mathrm{mol} \mathrm{H}_{2} \mathrm{O} \mathrm{cm}$ (Table 1).

The calibration of Paterson (1982) is given as follows:

$$
c=\int \frac{A_{\mathrm{h} \text { at } v / t}}{150 \cdot \gamma \cdot(3780-v)} \mathrm{d} v
$$

where $A_{\mathrm{h} \text { at } v}$ is the absorbance at the wave number $v\left(\mathrm{~cm}^{-1}\right), t$ is the thickness in $\mathrm{cm}$, and $\gamma$ is the orientation factor. The value of $\gamma=1 / 3$ is used for $\mathrm{H}_{2} \mathrm{O}$, as suggested by Paterson (1982), assuming an isotropic $\mathrm{OH}$ distribution, any beam direction, and any polarization. The denominator refers to the absorption coefficient, which depends linearly on the wave number, so that $\varepsilon_{\mathrm{h}}=150 \cdot \gamma \cdot(3780-v)\left[\mathrm{L} / \mathrm{mol} \mathrm{H} \mathrm{cm}{ }^{2}\right]$. Paterson (1982) also introduced the effective integral absorption coefficient as follows:

$$
\varepsilon_{\text {int eff }}=\frac{A_{\text {int }}}{c t},
$$

where $c$ is from Eq. (5) and $A_{\text {int }}$ is given as follows.

$$
A_{\text {int }}=\int A_{\text {h at } v} \mathrm{~d} v .
$$

In the calibration of Libowitzky and Rossman (1997), the mean wave number $\left(v_{\text {mean }}\right)$ was applied, and this is given by band deconvolution of the water stretching bands with integral absorbance of each band at each wave number. The IR spectra of our quartz samples show broad $\mathrm{H}_{2} \mathrm{O}$ stretching bands at $2800-3750 \mathrm{~cm}^{-1}$ with the maximum around $3400 \mathrm{~cm}^{-1}$ (Fig. 3), which can also be the mean. We used $3400 \mathrm{~cm}^{-1}$ as the $v_{\text {mean }}$. Then, the calibrations become $\varepsilon_{\text {int }}=246.6 \cdot \gamma \cdot\left(3753-v_{\text {mean }}\right)$ in L/ mol $\mathrm{H}_{2} \mathrm{O} \mathrm{cm}{ }^{2}$ using Libowitzky and Rossman (1997) $(\gamma$ is introduced in our study but was not employed in the original paper $)$, or $\varepsilon_{\text {int }}=300 \cdot \gamma \cdot\left(3780-v_{\text {mean }}\right)$ using Paterson (1982), thus giving 29,000 and $38,000 \mathrm{~L} / \mathrm{mol}$ $\mathrm{H}_{2} \mathrm{O} \mathrm{cm}$, respectively (Table 1 ). The differences from the original calibration of Paterson (1982) are $\pm \sim 10 \%$ in $\varepsilon_{\text {int }}$ eff as given by Eq. (6), and consequently water content, as given by Eq. (5). This simplification of the calibration of Paterson (1982) is helpful for comparing all the calibrations and for calculating water contents from large data sets of IR mapping, as we will show later.

Details of using all the various calibrations are given in Table 1, where the ratio of $c$ for each calibration means the ratio of $1 / \varepsilon_{\text {int }}$ from Eq. (2) (and Eqs. 1 and 4 for Nakashima et al. 1995). The ratio of $c$ in all calibrations varies from 0.43 (Thomas et al. 2009) to 1.58 (Stipp et al. 2006). This is also shown in Fig. 4 in the form of the determined integral absorbance. The large

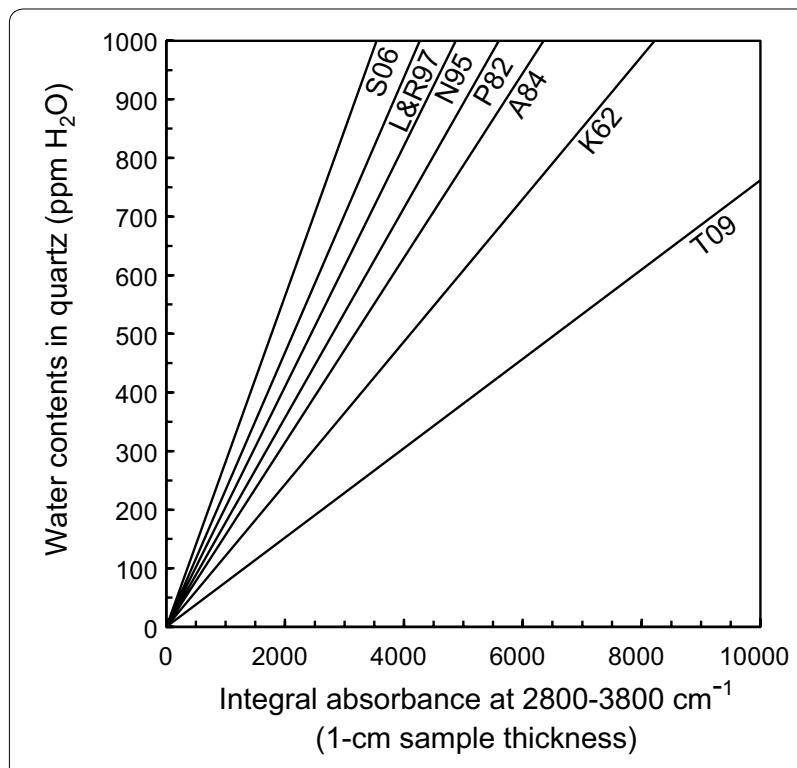

Fig. 4 Different calibrations used to calculate water contents and the integral absorbance of molecular $\mathrm{H}_{2} \mathrm{O}$. See Table 1 for the calibrations

differences among the calibrations may be associated roughly with the differences in the water species. Thomas et al. (2009) reported that the IR spectra for quartz consist mainly of $\mathrm{OH}$ sharp bands and that the value of $\varepsilon_{\text {int }}$ is $89,000 \mathrm{~L} / \mathrm{mol} \mathrm{H}_{2} \mathrm{O} \mathrm{cm}{ }^{2}$ (the maximum in Table 1), thus giving the lowest calculated water contents. Kats (1962) also showed OH sharp bands and an $\varepsilon_{\text {int }}$ value of $55,800 \mathrm{~L} / \mathrm{mol} \mathrm{H}_{2} \mathrm{O} \mathrm{cm}$. Aines et al. (1984) reported a higher contribution of molecular $\mathrm{H}_{2} \mathrm{O}$ for synthetic quartz samples, with an $\varepsilon_{\text {int }}$ value of $43,100 \mathrm{~L} /$ mol $\mathrm{H}_{2} \mathrm{O} \mathrm{cm}{ }^{2}$. The calibration of Paterson (1982) was designed for molecular $\mathrm{H}_{2} \mathrm{O}$ and assumes the orientation factor. The value of $\varepsilon_{\text {int }}$ is $38,000 \mathrm{~L} / \mathrm{mol} \mathrm{H}_{2} \mathrm{O} \mathrm{cm}$. The calibration of Nakashima et al. (1995) is based on the $\varepsilon_{\mathrm{h}}$ given by Thompson (1965) just for molecular $\mathrm{H}_{2} \mathrm{O}$, and the value of $\varepsilon_{\text {int }}$ is $33,200 \mathrm{~L} / \mathrm{mol} \mathrm{H}_{2} \mathrm{O} \mathrm{cm}{ }^{2}$ using Eq. (4). These two calibrations therefore yield similar $\varepsilon_{\text {int }}$ values. Broad bands were also reported by Stipp et al. (2006) with several $-\mathrm{OH}$ sharp bands $\left(\varepsilon_{\text {int }}\right.$ of $24,100 \mathrm{~L} / \mathrm{mol}$ $\mathrm{H}_{2} \mathrm{O} \mathrm{cm}$ ). Thomas et al.s (2009) $\varepsilon_{\text {int }}$ value of $89,000 \mathrm{~L} /$ mol $\mathrm{H}_{2} \mathrm{O} \mathrm{cm}^{2}$ was determined for crystallographically oriented samples and considering the orientations of $\mathrm{OH}$ in the quartz crystal structure. As carefully discussed in recent papers (Stalder and Konzett 2012; Baron et al. 2015; Frigo et al. 2016), the values of $\varepsilon_{\text {int }}$ for randomly distributed molecular $\mathrm{H}_{2} \mathrm{O}$ given by Paterson (1982), Libowitzky and Rossman (1997), and Stipp et al. (2006) are for unpolarized IR light irradiated to the sample. Therefore, Paterson (1982) (and for the data of Libowitzky and Rossman 1997 in the present study) applied an 
orientation factor $\gamma=1 / 3$, assuming an isotropic distribution of the water in quartz. Consequently, three times the $\varepsilon_{\text {int }}$ values of Paterson (1982), Libowitzky and Rossman (1997), and Stipp et al. (2006) $(38,000 \times 3=114,000$, $29,000 \times 3=87,000$, and $24,100 \times 3=72,300 \mathrm{~L} / \mathrm{mol}$ $\mathrm{H}_{2} \mathrm{O} \mathrm{cm}$, respectively) can give rather similar values to the $\varepsilon_{\text {int }}$ value given by Thomas et al. (2009) $(89,000 \mathrm{~L} /$ $\mathrm{mol} \mathrm{H}_{2} \mathrm{O} \mathrm{cm}^{2}$ ). The same argument can be applied to the $\varepsilon_{\text {int }}$ value given by Thompson (1965), which with our modification is $33,200 \times 3=99,600 \mathrm{~L} / \mathrm{mol} \mathrm{H}_{2} \mathrm{O} \mathrm{cm}{ }^{2}$. In Aines et al. (1984), their $\varepsilon_{\text {int }}$ includes one direction twice in their determination of the $\varepsilon_{\text {int }}$. Thus, twice their $\varepsilon_{\text {int }}$ value $\left.\left(43,100 \times 2=86,200 \mathrm{~L} / \mathrm{mol} \mathrm{H}_{2} \mathrm{O} \mathrm{cm}\right)^{2}\right)$ gives a similar value to that of Thomas et al. (2009). Please also see the detailed discussions in Stalder and Konzett (2012), Baron et al. (2015), and Frigo et al. (2016). In summary, molecular $\mathrm{H}_{2} \mathrm{O}$ may give lower values of $\varepsilon_{\text {int }}$ than the $\mathrm{OH}$ species when there are specific orientations of the water species in the quartz crystal structure relative to the orientations of the irradiated IR light. Thus, when IR spectra are used to determine the water content, one first needs to clarify the spectral features with contributions of molecular $\mathrm{H}_{2} \mathrm{O}$ and the $-\mathrm{OH}$ species, and at present we also need to show how each calibration gives different values of water content depending on the values of the absorption coefficients.

\section{Determination of water content distribution from the IR mapping results}

To calculate the water contents from the large data sets of IR mapping, we used the simplified calibration of Paterson (1982) following the approach of Libowitzky and Rossman (1997). We used the $v_{\text {mean }}$ value of $3400 \mathrm{~cm}^{-1}$ and the orientation factor of $\gamma=1 / 3$ designed for $\mathrm{H}_{2} \mathrm{O}$ (Table 1), because the IR spectra of the quartz in our samples show dominant $\mathrm{H}_{2} \mathrm{O}$ bands (Fig. 3). As mentioned in the previous section, this method is for unpolarized IR light plus randomly orientated water. We note that the values of $v_{\text {mean }}$ and the orientation factor would change if other $-\mathrm{OH}$ components in the IR spectra were introduced (e.g., contributions from phyllosilicates in our specimens). However, in order to focus on the water contents in quartz in our mapping results, Eq. (3) for quartz was applied. Therefore, the calculated water contents for aggregates including quartz and some other minerals give rough or tentative estimates. Some spectra include weak organic bands around $2900 \mathrm{~cm}^{-1}$ that would be due to the resin used for polishing, but these bands do not affect the water bands.

\section{Results}

We performed IR mapping of quartz-rich regions in specimens of the Sanbagawa metamorphic rocks with different grades of metamorphism. Figure 5 shows the results for the sample from the chlorite zone (No. 7-93), the lowest grade metamorphic rock. The measured area in Fig. 5 includes phyllosilicates (Fig. 5a, b). The quartz
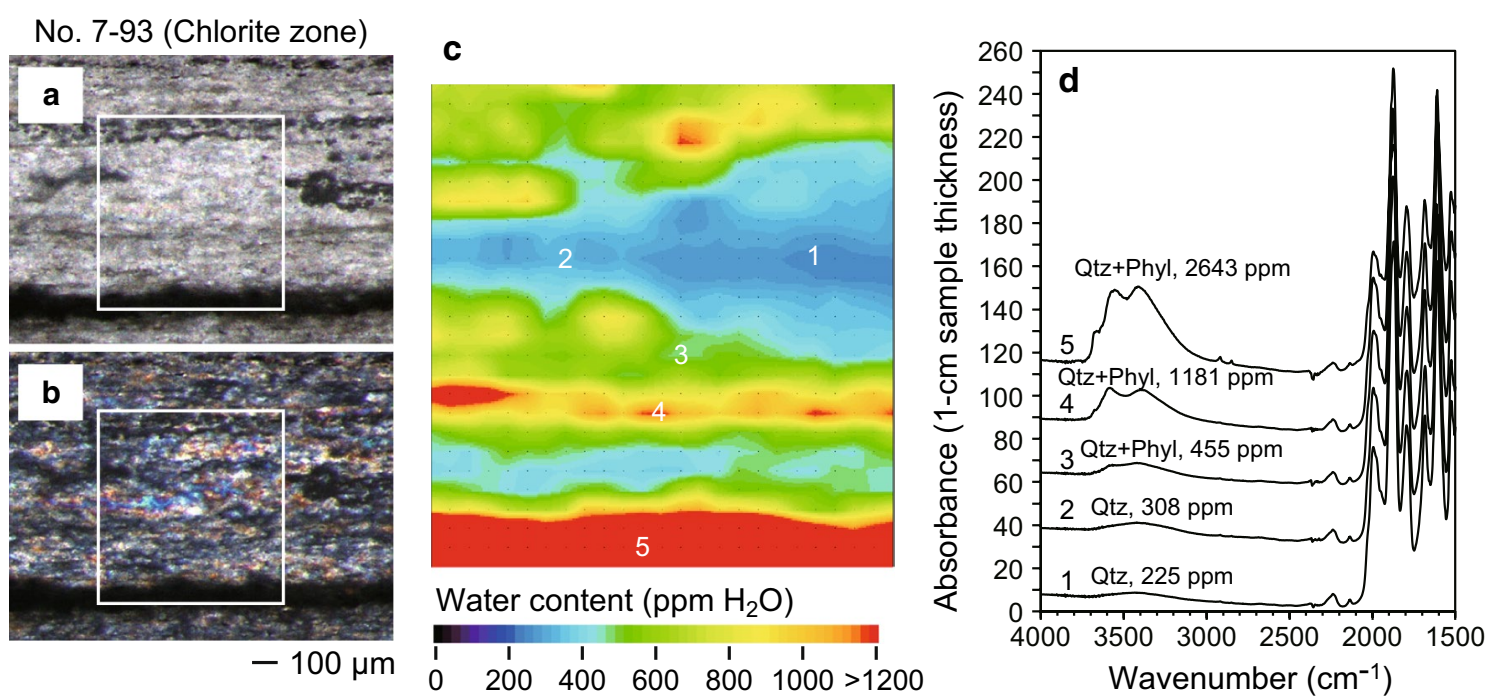

Fig. 5 IR mapping result for chlorite-zone specimen No. 7-93. a Optical photomicrograph, plane-polarized light. b Cross-polarized light. The IR mapped areas are shown by squares. c Water distributions using the calibration of Paterson (1982). Numbers represent raw IR spectra in d. Spectra for the lowest (line 1) and highest (line 2) water contents are shown. Other spectra are mixtures of quartz (Qtz) and phyllosilicates (Phyl) and show large variations in band components and water contents 
grain size is $<40 \mu \mathrm{m}$, the sample thickness $\sim 100 \mu \mathrm{m}$, and the aperture size for IR spectroscopy $30 \times 30 \mu \mathrm{m}$. Therefore, the IR-measured area includes quartz grain boundaries where molecular $\mathrm{H}_{2} \mathrm{O}$ might be trapped. The water distribution according to the IR mapping measurements shows that when only the quartz aggregate is analyzed, the water contents range from 225 to 308 wt ppm $\mathrm{H}_{2} \mathrm{O}$ with the representative value of $\sim 280 \mathrm{ppm}$ (namely, the value that is widely seen in the measured area) (Fig. 5c, d). When phyllosilicates are included, the water contents become much higher (>400 ppm, as in spectra 3-5 in Fig. 5d). The spectra of water bands in these situations consist of bands around 3560 and $3640 \mathrm{~cm}^{-1}$ on a broad band of molecular $\mathrm{H}_{2} \mathrm{O}$. All these bands would be associated with chlorite, and the nature of the components and their wave numbers probably change according to the type of phyllosilicate and its composition, among other factors (e.g., Oinuma and Hayashi 1965; Prieto et al. 1991). The structural vibrations of phyllosilicates at $<2300 \mathrm{~cm}^{-1}$ are not clearly seen because of the dominant structural bands of quartz (Fig. 5). However, when large amounts of phyllosilicate are included (showing high water stretching absorption bands), the component of the quartz structural bands decreases slightly, especially around $1990 \mathrm{~cm}^{-1}$. Phyllosilicates are commonly observed in the optical photomicrographs, and this is reflected in the corresponding IR mapping results. However, some phyllosilicates may appear dusty or be obscured in an optical photomicrograph (e.g., be located in a deep part of the thin section and/or the contents are low), but this problem is addressed by paying attention to other well-observed and identified phyllosilicates in the area. Even when a phyllosilicate grain is not clearly defined, the relatively broad bands around 3560 and $3640 \mathrm{~cm}^{-1}$, which may be combined, often reveal its presence (e.g., Spectrum 3 in Fig. 5c, d).

The mean grain size of quartz in the garnet zone sample (No. 7-45) is $\sim 80 \mu \mathrm{m}$ (Fig. 6b), which is $\sim 40 \mu \mathrm{m}$ larger than in the chlorite zone. The range of water contents in the quartz is $94-210 \mathrm{ppm}$ with the representative value of $\sim 190 \mathrm{ppm}$ (Fig. 6c, d), which is $90 \mathrm{ppm}$ lower than in chlorite-zone specimen No. 7-93. The IR spectra exhibit a band at $3610 \mathrm{~cm}^{-1}$ in the measured area, when phyllosilicates are included (lines 3-5 in Fig. 6d). With increasing amounts of phyllosilicate, the broad band at $2800-3750 \mathrm{~cm}^{-1}$, which would probably include both $\mathrm{H}_{2} \mathrm{O}$ and other $-\mathrm{OH}$ components, becomes high. The spectrum around $3400 \mathrm{~cm}^{-1}$ appears to be more intense than the typical $\mathrm{H}_{2} \mathrm{O}$ band and has shoulders around 3425 and $3020 \mathrm{~cm}^{-1}$. Similar spectral features were reported by Kilian et al. (2016). When these bands due to phyllosilicates (most likely biotite in this case) become high, the component of the structural vibrations of quartz, especially around $1990 \mathrm{~cm}^{-1}$, becomes less than other bands, probably because of the structural vibrations of the phyllosilicate.

In the oligoclase-biotite schist (specimen No. 7-26), which represents the highest metamorphic grade in the study area, the measured area includes a single host grain of quartz $(>500 \mu \mathrm{m})$ with recrystallized grains of $<120 \mu \mathrm{m}$ (Fig. 7). Water contents of 39-87 ppm with
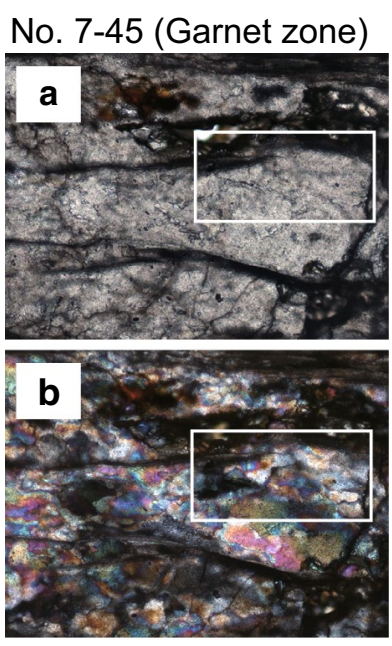

$$
-100 \mu \mathrm{m}
$$

c

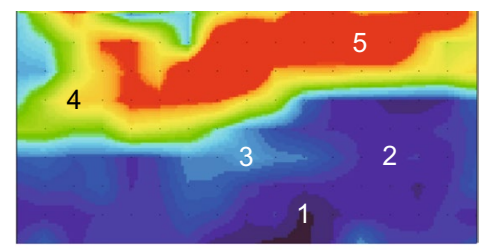

Water content (ppm $\left.\mathrm{H}_{2} \mathrm{O}\right)$

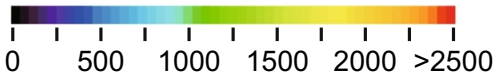

d

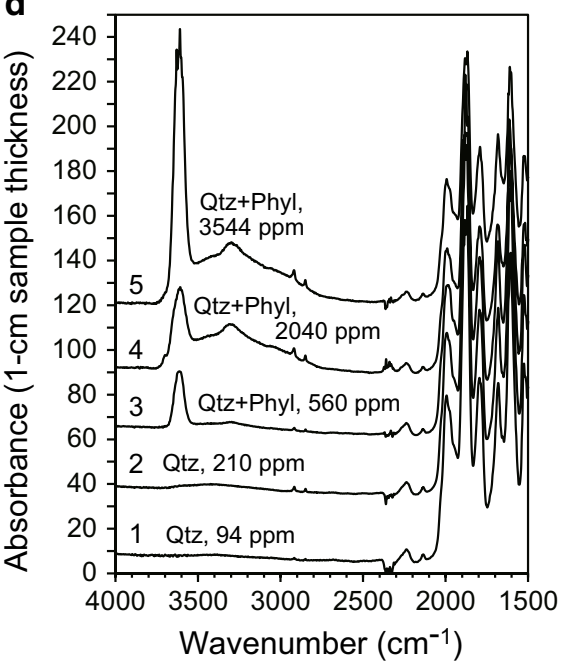

Fig. 6 IR mapping result for garnet zone specimen No. 7-45. a Optical photomicrograph, plane-polarized light. b Cross-polarized light. The IR mapped areas are shown by squares. $\mathbf{c}$ Water distributions using the calibration of Paterson (1982). Numbers represent raw IR spectra in $\mathbf{d}$ 

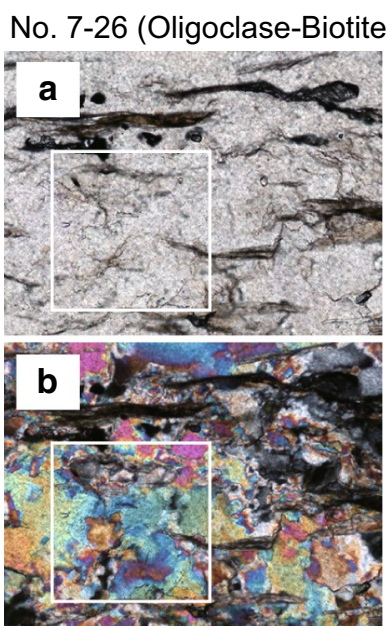

$-100 \mu \mathrm{m}$ c

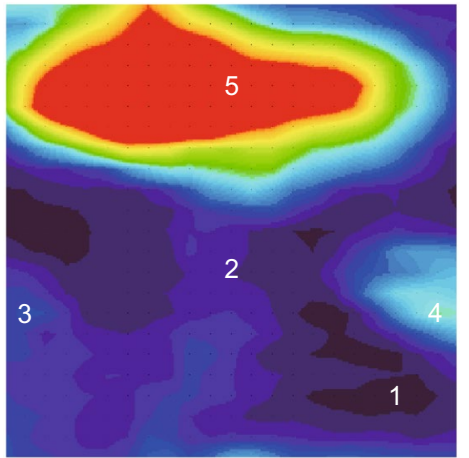

Water content $\left(\mathrm{ppm} \mathrm{H}_{2} \mathrm{O}\right)$

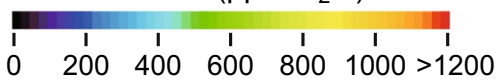

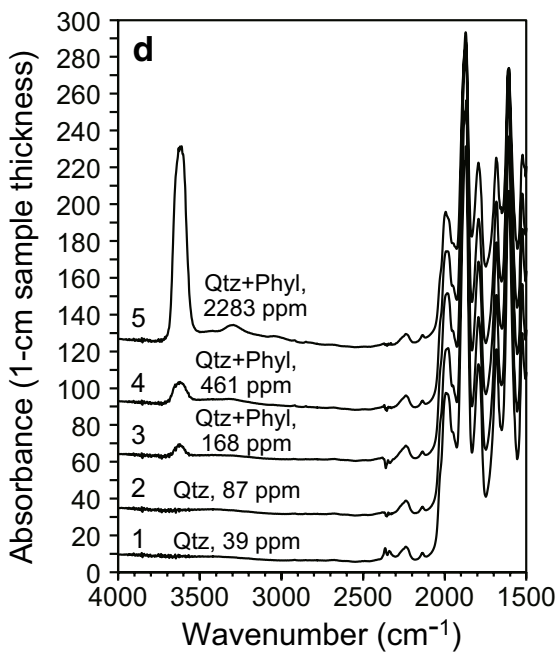

Fig. 7 IR mapping result for oligoclase-biotite zone specimen No. 7-26, which represents the highest grade of metamorphism in the study area. a Optical photomicrograph, plane-polarized light. $\mathbf{b}$ Cross-polarized light. The IR mapped areas are shown by squares. $\mathbf{c}$ Water distributions using the calibration of Paterson (1982). Numbers represent raw IR spectra in $\mathbf{d}$

the representative value of $\sim 70 \mathrm{ppm}$ were measured, the lowest of all the samples (Fig. 7c, d). The relationship between the water contents in the host quartz grain and those in the recrystallized grains is unclear.

Sample No. 7-35 from the albite-biotite zone includes quartz grains that are $>120 \mu \mathrm{m}$ in size (Fig. 8a, b). The sample shows alignments of fluid inclusions (Fig. 8a) that are not associated with features of plastic deformation such as undulose extinction or subgrains, and the fluid inclusions would have been trapped after the plastic deformation took place, during a stage of brittle deformation that was accompanied by an influx of water and crack healing. The lowest water content is $\sim 40 \mathrm{ppm}$, which is similar to that in the highest metamorphic grade sample (No. 7-26, Fig. 7). The areas with fluid inclusions show higher water contents of up
No. 7-35 (Albite-Biotite zone)
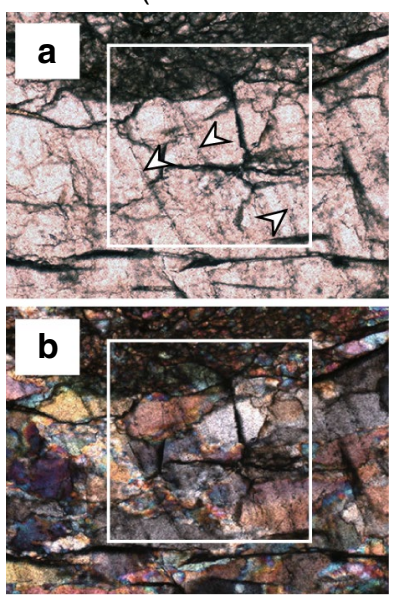

$-100 \mu \mathrm{m}$ c

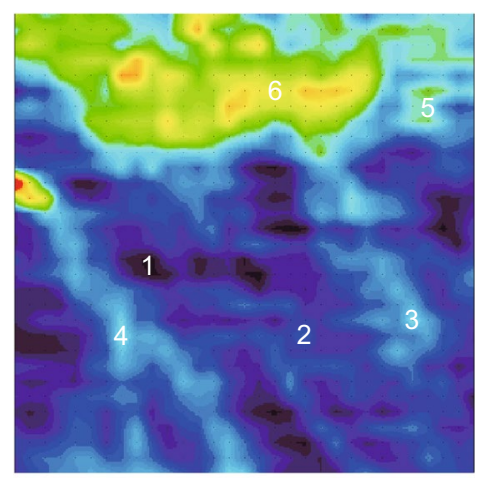

Water content $\left(\mathrm{ppm} \mathrm{H}_{2} \mathrm{O}\right)$

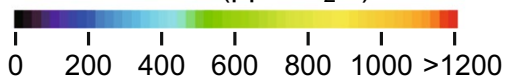

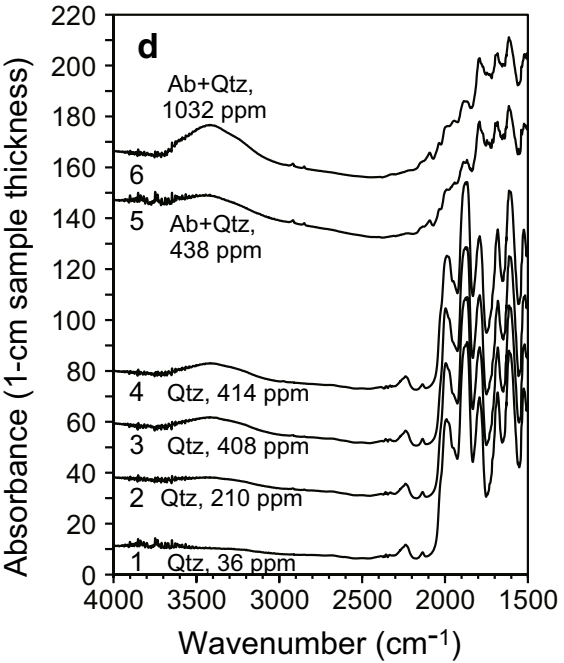

Wavenumber $\left(\mathrm{cm}^{-1}\right)$

Fig. 8 IR mapping result for albite-biotite zone specimen No. 7-35, which shows aligned fluid inclusions. a Optical photomicrograph, plane-polarized light. b Cross-polarized light. Cracks are also seen. The aligned fluid inclusions in the quartz are indicated by arrows. The IR mapped areas are shown by squares. $\mathbf{c}$ Water distributions using the calibration of Paterson (1982). Numbers represent raw IR spectra in $\mathbf{d}$. Aligned fluid inclusions show relatively high values (lines 3 and 4) 
to $\sim 410 \mathrm{ppm}$ and exhibit the same spectral features of molecular $\mathrm{H}_{2} \mathrm{O}$. The water contents of an albite porphyroblast (with minor quartz) are 400-1100 ppm (Fig. 8c), and the IR spectra show typical molecular $\mathrm{H}_{2} \mathrm{O}$ bands (Fig. 8d).

\section{Discussion}

The relationship between water content of quartz and metamorphic grade is shown in Fig. 9. The distances in kilometers are to the north from the intersection of the Yoshino and Asemi Rivers (Fig. 1), and each location was traced on a straight line. The data for specimen No. 7-35 are not included since the measured area for that specimen included complicated alignments of secondary fluid inclusions in healed cracks (Fig. 8). The water contents measured by Nakashima et al. (1995) are also shown, after modifying their calibration to fit with the calibration of Paterson (1982) (see Eq. (4) and Table 1).

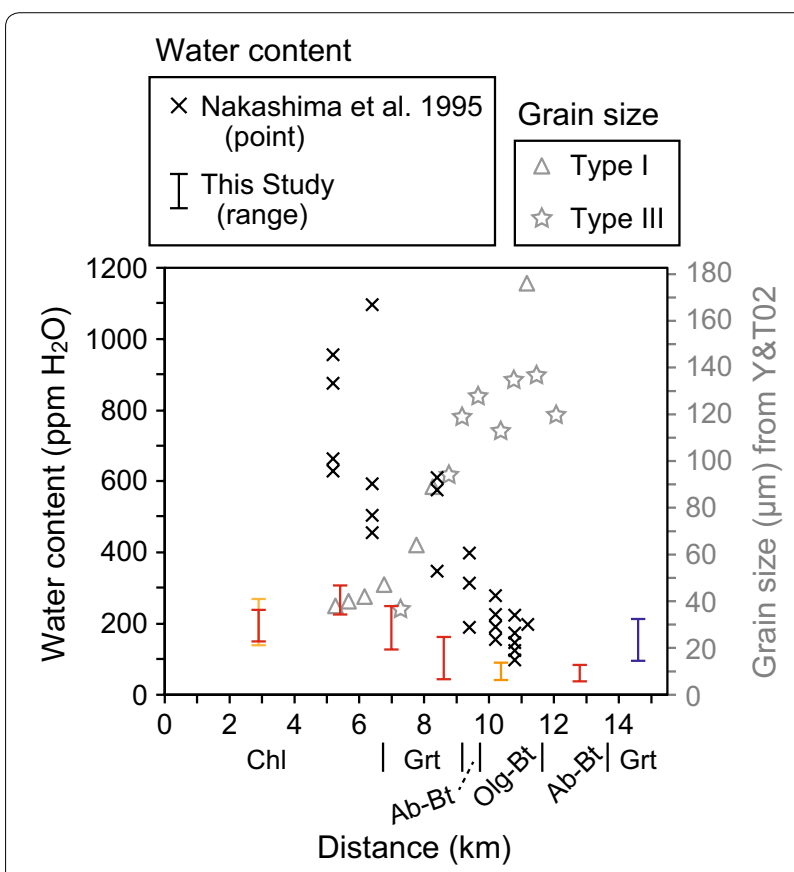

Fig. 9 Water distributions in quartz in Sanbagawa metamorphic rocks of various metamorphic grades along the Asemi River. The ranges of water content obtained by us using IR mapping are shown. Data from Nakashima et al. (1995) obtained by point analyses are also shown after modifying their calibration to fit the calibration of Paterson (1982). Data for the grain sizes of quartz and grain morphologies are from Yagi and Takeshita (2002). (They reported type-I and type-III grains, but no type-II grains.) Note that the locations and textures of their specimens are not exactly the same as ours. The distances in kilometers are measured to the north of the intersection between the Yoshino and Asemi Rivers (Fig. 1), and each location was traced along a straight line. For our samples, blue indicates pelitic rock, yellow indicates psammitic rock, and red indicates siliceous rock
Data for the average grain size of quartz and microstructural types are from Yagi and Takeshita (2002). Our IR results show that the water contents of quartz are highest at $\sim 310 \mathrm{ppm}_{2} \mathrm{O}$ in the chlorite zone, which represents the lowest metamorphic grade. The water contents gradually decrease with increasing metamorphic grade, and they are lowest at $\sim 40 \mathrm{ppm}$ in the oligoclase-biotite zone. In the same area, Nakashima et al. (1995) also showed that the water contents of quartz decrease with increasing metamorphic grade, but the values of water content they determined are much higher than ours. Again, we modified their calibration to fit the calibration of Paterson (1982) used in the present study, and we directly compared their water content values with ours, as shown in Fig. 9. The water contents they determined using point analyses, and adjusted by us, decrease from $450-1100 \mathrm{ppm}$ in the chlorite zone to $90-240 \mathrm{ppm}$ in the biotite zone. They argued that because lower-grade rocks have smaller grain sizes, the grain boundary volumes are correspondingly large, and that it is along the grain boundaries where larger amounts of molecular $\mathrm{H}_{2} \mathrm{O}$ can be trapped. However, numerous grains of phyllosilicates (chlorite and mica) are spaced irregularly between the quartz grains in the low-grade samples, and only limited areas could be chosen for the IR analyses, but even so, the IR mapping inevitably included tiny phyllosilicate grains, which have higher water contents than the quartz (Figs. 5, $6,7,8)$. The IR point measurements of Nakashima et al. (1995), especially for samples of low-grade metamorphic rocks, may therefore have included phyllosilicates as well as small quartz grains.

Ito and Nakashima (2002) similarly performed IR mapping analyses of natural chert and shale in the Northern Chichibu Belt of the Kanto Mountains, Central Japan, as well as natural Brazilian agate, and they derived a relationship between water content and grain size, and estimated grain boundary width filled with molecular $\mathrm{H}_{2} \mathrm{O}$, which we will discuss later. The Northern Chichibu Belt is the lowest grade part of the 'Sanbagawa Metamorphic Belt' in its broad sense (Shimizu 1988). Some of their IR spectra show a band around $3600 \mathrm{~cm}^{-1}$. In view of the above discussion, we suggest this band as well as the molecular $\mathrm{H}_{2} \mathrm{O}$ band may be attributed to phyllosilicates. The band around $3600 \mathrm{~cm}^{-1}$ can also be attributed to dislocation $\mathrm{Si}-\mathrm{OH}$ that has been found in dynamically recrystallized natural quartz (Niimi et al. 1999; Gleason and DeSisto 2008) and experimentally deformed quartz single crystals (Stünitz et al. 2017). Stünitz et al. (2017) showed that this band disappears after annealing due to the disappearance of dislocations. The band related to dislocation $\mathrm{Si}-\mathrm{OH}$ is much sharper than the band due to $-\mathrm{OH}$ in phyllosilicate (Figs. 5, 6, 7). Contents of dislocation $\mathrm{Si}-\mathrm{OH}$ in quartz under various pressure and 
temperature conditions are estimated from thermodynamics to be less than $100 \mathrm{H} / 10^{6} \mathrm{Si}$ (i.e., 15 wt ppm $\mathrm{H}_{2} \mathrm{O}$ ), assuming $\mathrm{Si}-\mathrm{O}$ bonds are replaced by $\mathrm{Si}-\mathrm{OH}$ (namely, $\mathrm{H}_{4} \mathrm{O}_{4}$ tetrahedra) (Paterson 1986). In contrast, IR studies of chalcedony and agate have estimated $\mathrm{H}_{2} \mathrm{O}$ and $\mathrm{Si}-\mathrm{OH}$ contents of $>1 \mathrm{wt} \%$ each (Flörke et al. 1982; Graetsch et al. 1985). These values were estimated from the clear stretching and bending combination bands around 5200 and $4500 \mathrm{~cm}^{-1}$ in their IR spectra. The $\mathrm{H}_{2} \mathrm{O}$ and $\mathrm{Si}-\mathrm{OH}$ contents of our chalcedony were estimated to be $\sim 0.3 \mathrm{wt} \%$ each (Fukuda et al. 2009a). In addition to the dislocation $\mathrm{Si}-\mathrm{OH}$ in chalcedony, $\mathrm{Si}-\mathrm{OH}$ can also be associated with surface $\mathrm{Si}-\mathrm{OH}$ at grain boundaries because of the fine grain size (e.g., a few hundred nanometers). In any case, previous IR studies of quartz demonstrated that even when only dislocation $\mathrm{Si}-\mathrm{OH}$ was included, the band at $3585 \mathrm{~cm}^{-1}$ was observed (Kronenberg and Wolf 1990; Kronenberg et al. 1990; Kronenberg 1994; Niimi et al. 1999; Gleason and DeSisto 2008; Stünitz et al. 2017). However, when phyllosilicates are not included in the analyses of our schist samples, the band due to $\mathrm{Si}-\mathrm{OH}$ is not seen. This may indicate that the dislocation density in the quartz schists was lowered by dynamic recovery, and that the influence of dislocation $\mathrm{Si}-\mathrm{OH}$ was not important in the part of the Sanbagawa Metamorphic Belt examined in the present study.

Finch et al. (2016) demonstrated that the water content of quartz decreases with the development of mylonite and ultimately ultramylonite, where the mean matrix grain size decreases from 95 to $60 \mu \mathrm{m}$ as a result of dynamic recrystallization. They measured only intragranular water, which means that no grain boundaries were included. Their IR spectra for quartz also show the dominant stretching vibration bands of molecular $\mathrm{H}_{2} \mathrm{O}$. The water contents they reported using the calibration of Kats (1962) ranged from $3265 \mathrm{ppm} \mathrm{H/Si} \mathrm{in} \mathrm{weakly} \mathrm{deformed}$ quartz to $1455 \mathrm{ppm} \mathrm{H/Si} \mathrm{in} \mathrm{the} \mathrm{ultramylonite.} \mathrm{These}$ values correspond, respectively, to $\sim 720$ and $320 \mathrm{ppm}$ $\mathrm{H}_{2} \mathrm{O}$, using the calibration of Paterson (1982) (Table 1). The absolute values could be related to the water environment of the original quartz grains and the conditions of metamorphism and deformation, so it is not possible to directly compare them with our results. The most interesting finding of Finch et al. (2016) was that the intragranular water content decreases as dynamic recrystallization progresses, and they proposed that the water was swept out during the recrystallization process (subgrain rotation or grain boundary migration, depending on the sample). On the other hand, our higher-grade samples taken from the garnet and biotite zones show lower water contents down to $\sim 40 \mathrm{ppm} \mathrm{H}_{2} \mathrm{O}$ (Fig. 9), which would be associated with the minimum intragranular water contents of the quartz grains. It is possible that the reduction in water content with increasing metamorphic grade was linked to the sweeping out of water with progressive metamorphism. In the chlorite zone, where the mean quartz grain size is $\sim 40 \mu \mathrm{m}$, the water contents are up to $310 \mathrm{ppm}$, which would be largely due to water along grain boundaries as discussed below.

Microstructures of quartz schists along the Asemi River show large variations under the microscope, consistent with descriptions made previously (Masuda 1982; Hara et al. 1988, 1992; Yagi and Takeshita 2002). Laboratory studies on quartz aggregates have revealed that the size and morphology of recrystallized grains depend on temperature and strain rate (Masuda and Fujimura 1981; Hirth and Tullis 1992). The dislocation creep regimes 1 to 3 of Hirth and Tullis (1992) describe the processes of grain size reduction in coarse-grained quartzite samples, whereas the P-and S-types of Masuda and Fujimura (1981) represent steady-state microstructures resulting from overall coarsening of agate samples. The relationships between these different classifications are explained in Fig. 5 of Shimizu (2008). Quartz schists in the Sanbagawa Metamorphic Belt are metacherts, and therefore regimes 1 to 3 of Hirth and Tullis (1992) are not applicable. However, the development of subgrains and the occurrence of lobate grain boundaries indicate that both subgrain rotation and migration recrystallization (that characterize regime 3) were active in all the quartz schists studied. Experimental and theoretical studies of dynamic recrystallization indicate a reduction in average grain size with increasing strain rate and/or decreasing temperature, both of which result in increasing differential stress (e.g., Shimizu 2008, 2011, 2012). The relationships between average grain size and metamorphic grade are, at a first approximation, understood by the temperature dependence of the dynamically recrystallized grain size. The amount of grain boundary water would be higher in rocks of lower metamorphic grade.

Assuming cubic or tetradecahedral grain shapes, the water content $w$ at a grain boundary in wt ppm is expressed as

$$
w=1132 \text { (for a cube) or } 894 \text { (for a tetradecahedron) } \times \delta / d
$$

where $\delta$ is the grain boundary width in $\mathrm{nm}$ and $d$ is the grain size in $\mu \mathrm{m}$ (Ito and Nakashima 2002). Using this equation, the water contents in the chert and agate samples studied by Ito and Nakashima (2002) vary from $\sim 300$ wt ppm $\mathrm{H}_{2} \mathrm{O}$ (for chert with the grain size of $17.5 \mu \mathrm{m}$ ) to $\sim 9000 \mathrm{wt}$ ppm $\mathrm{H}_{2} \mathrm{O}$ (for agate with the grain size of $1 \mu \mathrm{m}$ ) (Fig. 8 of Ito and Nakashima 2002), following the calibration of Nakashima et al. (1995), which can be converted into $\sim 260 \mathrm{wt}$ ppm for the chert and $\sim 7830 \mathrm{wt}$ ppm for the agate using the calibration of 
Paterson (1982) (Table 1). In the quartz schists of the present study, the lowest water content of $40 \mathrm{ppm} \mathrm{H}_{2} \mathrm{O}$ was from a single quartz crystal that was visible under the optical microscope and larger than the aperture size of 30 or $50 \mu \mathrm{m}$ of the IR microspectrometry equipment and larger than the sample thickness of $80-120 \mu \mathrm{m}$ (Figs. 6, $7,8)$. In contrast, the measured water contents of up to $310 \mathrm{ppm}$ from the chlorite zone would have included both intragranular and grain boundary water. Assuming that the intracrystalline water contents are almost constant and that the observed differences in water contents in the quartz-rich parts are due to grain boundary water, the differences in the water contents from $310 \mathrm{ppm}$ (intragranular and grain boundary water in the chlorite zone) to $40 \mathrm{ppm}$ (intragranular water in the biotite zones) (Fig. 9) show that the grain boundary width was $\sim 10 \mathrm{~nm}$ in all our samples. This value of grain boundary width is consistent with that estimated by Ito and Nakashima (2002) for the chert and agate, each of which has different water contents and grain sizes. However, it should be noted that some of their measurements with the relatively broad band around $3600 \mathrm{~cm}^{-1}$ may include phyllosilicates that would give high $\mathrm{H}_{2} \mathrm{O}$ contents, as discussed above.

The amount of grain boundary fluid in the chlorite zone along the Asemi River was also estimated by Hiraga et al. (2001) on the basis of morphological observations of grain boundaries using high-resolution transmission electron microscopy (HTEM). They observed lensshaped fluid at grain boundaries as well as fluid at triple junctions of combinations of quartz and/or albite grains (e.g., quartz-quartz-albite or quartz-albite-albite). Their estimation of the fluid volume from morphology was $\sim 0.05$ vol\%. They also measured IR spectra and showed dominant $\mathrm{H}_{2} \mathrm{O}$ bands similar to ours. Their water content calculations using the calibration of Nakashima et al. (1995) were consistent with those estimated from grain boundary morphology. Assuming that the grain boundary fluid was previously distributed uniformly, the average width of a grain boundary was estimated to be $\sim 6 \mathrm{~nm}$ (Hiraga et al. 2012), which is comparable with our estimation based on IR measurements and an assumed grain morphology (Eq. 8). However, unlike polygonal structures that result from static grain growth (e.g., Fukuda et al. 2019), the actual grain shapes in dynamically recrystallized quartz rocks of the type-I and typeIII are not close to cubes or tetradecahedra, and grain boundaries show curved or serrated morphologies (Takahashi et al. 1998). Moreover, grain size distribution in dynamic recrystallization is close to lognormal, which means that the grains smaller than the average size are large in number (Shimizu 1998, 1999). Hence, the grain boundary width evaluated by the above simple calculation is considered to be an upper limit. The width of a grain boundary without a fluid phase was estimated to be less than $0.5 \mathrm{~nm}$ by HTEM for granite ultramylonite from the Hatagawa Fault, NE Japan (Hiraga et al. 1999). This value gives the lower bound for grain boundary width. Since there are few data for the water contents of naturally deformed quartz, further studies are needed to understand the behavior of water in nature, as well as the textures that form under different conditions of deformation and metamorphism. However, our IR mapping results have shown that it is possible to make realistic correlations between the development of quartz textures and the contents of intragranular water in quartz or grain boundary water, while also considering the effects of phyllosilicate minerals. A knowledge of the differences in the various proposed IR calibrations, and their validity, is essential when estimating water contents in quartz.

\section{Conclusions}

We measured the water contents of deformed quartz in Sanbagawa metamorphic rocks of different metamorphic grade from the chlorite to biotite zones. We examined previously reported IR calibrations for determining the water contents of quartz, and we unified these previous calibrations as an absorption coefficient in $\mathrm{L} / \mathrm{mol}$ $\mathrm{H}_{2} \mathrm{O} \mathrm{cm}$. The value of this coefficient varies from 24,100 (Stipp et al. 2006) to 89,000 (Thomas et al. 2009), which roughly corresponds to the increase in the components of structural $-\mathrm{OH}$ in IR spectra (probably when $-\mathrm{OH}$ species are orientated in the quartz crystal structure) and to the decrease in components of molecular $\mathrm{H}_{2} \mathrm{O}$. (This could also be orientated in some cases.) We used the calibration of Paterson (1982) for molecular $\mathrm{H}_{2} \mathrm{O}$ $\left(\varepsilon_{\text {int }}=38,000 \mathrm{~L} / \mathrm{mol} \mathrm{H}_{2} \mathrm{O} \mathrm{cm}{ }^{2}\right)$. Our IR mapping results for quartz in the Sanbagawa metamorphic rocks, considering the progressive changes in texture, reveal that the water contents, dominantly molecular $\mathrm{H}_{2} \mathrm{O}$ trapped

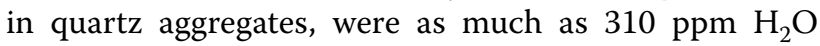
(2070 ppm H/Si) in the chlorite zone (including at grain boundaries) and as low as $40 \mathrm{ppm} \mathrm{H}_{2} \mathrm{O}(270 \mathrm{ppm} \mathrm{H} / \mathrm{Si})$ in the biotite zone (possibly as intracrystalline water). We suggest that this progressive decrease in water content relates to the progressive decrease in the grain boundary volume as grain size increases. Thus, the maximum possible difference in water content $\left(270 \mathrm{ppm} \mathrm{H}_{2} \mathrm{O}\right)$ is the amount that can be trapped at grain boundaries, which gives an estimated grain boundary width of up to $\sim 10 \mathrm{~nm}$ for a grain size of $40 \mu \mathrm{m}$.

\section{Acknowledgements}

The authors thank T. Ueda for discussions on sample microstructures and K. Shinoda for discussions on processing IR data and for comments on the manuscript. Reviews by two anonymous reviewers and editorial handling by $\mathrm{T}$. Matsuzawa are acknowledged. 


\section{Authors' contributions}

JF performed the analyses and drafted the manuscript with contributions from IS. IS collected samples and designed the framework of this study. Both authors read and approved the final manuscript.

\section{Funding}

This research was supported by a Grant-in-Aid for Scientific Research (KAKENHI 19K04041) from the Japan Society for the Promotion of Science (JSPS) to JF and by Grants-in-Aid for Scientific Research on Innovative Areas (KAKENHI $15 K 21755$ and 26109005) from the Ministry of Education, Culture, Sports, Science, and Technology (MEXT) to IS.

\section{Availability of data and materials}

The data are available from the corresponding author (JF) upon request (jfukuda@crystal.kobe-u.ac.jp). Samples and thin sections of quartz schists are held in the laboratory of the second author (IS) at Kyoto University.

\section{Competing interests}

The authors declare that they have no competing interests.

\begin{abstract}
Author details
${ }^{1}$ Department of Earth and Planetary Science, The University of Tokyo, 7-3-1 Hongo, Bunkyo-ku, Tokyo 113-0033, Japan. ${ }^{2}$ Institut des Sciences de la Terre d'Orléans, UMR 7327, Université d'Orléans, 1 a rue de la Férollerie, 45071 Orléans, France. ${ }^{3}$ Present Address: Research Center for Inland Seas, Kobe University, 1-1 Rokkodai-cho, Nada-ku, Kobe, Hyogo 657-8501, Japan. ${ }^{4}$ Division of Earth and Planetary Sciences, Kyoto University, Kitashirakawa Oiwake-cho, Sakyo-ku, Kyoto 606-8052, Japan.
\end{abstract}

Received: 16 August 2019 Accepted: 23 November 2019 Published online: 05 December 2019

\section{References}

Aines RD, Kirby SH, Rossman GR (1984) Hydrogen speciation in synthetic quartz. Phys Chem Miner 11:204-212. https://doi.org/10.1007/BF003 08135

Banno S, Higashino T, Otsuki M, Itaya T, Nakajima T (1978) Thermal structure of the Sanbagawa metamorphic belt in central Shikoku. J Phys Earth 26(Suppl):S345-S356. https://doi.org/10.4294/jpe1952.26.Supplement S345

Baron MA, Stalder R, Hauzenberger CA (2015) OH-point defects in quartz in Band Li-bearing systems and their application to pegmatites. Phys Chem Miner 42:53-62. https://doi.org/10.1007/s00269-014-0699-4

Chernak LJ, Hirth G, Selverstone J, Tullis J (2009) Effect of aqueous and carbonic fluids on dislocation creep strength of quartz. J Geophys Res 114:B04201. https://doi.org/10.1029/2008JB005884

Enami M, Wallis SR, Banno Y (1994) Paragenesis of sodic pyroxene-bearing quartz schists: implications for the P-T history of the Sanbagawa belt. Contrib Mineral Petrol 116:182-198. https://doi.org/10.1007/BF00310699

Finch MA, Weinberg RF, Hunter NJR (2016) Water loss and the origin of thick ultramylonites. Geology 44:599-602. https://doi.org/10.1130/G37972.1

Flörke OW, Heibertz-Köhler B, Tönges I (1982) Water in microcrystalline quartz of volcanic origin: agates. Contrib Mineral Petrol 80:324-333. https://doi. org/10.1007/BF00378005

Frigo C, Stalder R, Hauzenberger CA (2016) OH defects in quartz in granitic systems doped with spodumene, tourmaline and/or apatite: experimental investigations at 5-20 kbar. Phys Chem Miner 43:717-729. https://doi. org/10.1007/s00269-016-0828-3

Frondel C (1982) Structural hydroxyl in chalcedony (Type B quartz). Am Mineral 67:1248-1257

Fukuda J (2012) Water in rocks and minerals - species, distributions, and temperature dependences. In: Theophanides T (ed) Infrared spectroscopymaterials science, engineering and technology. Intech, Rijeka, pp 77-96. https://doi.org/10.5772/35668

Fukuda J, Nakashima S (2008) Water at high temperatures in a microcrystalline silica (chalcedony) by in situ infrared spectroscopy: physicochemical states and dehydration behavior. J Mineral Petrol Sci 103:112-115. https ://doi.org/10.2465/jmps.071022a
Fukuda J, Shimizu I (2017) Theoretical derivation of flow laws for quartz dislocation creep: comparisons with experimental creep data and extrapolation to natural conditions using water fugacity corrections. J Geophys Res 122:5956-5971. https://doi.org/10.1002/2016JB013798

Fukuda J, Peach CJ, Spiers CJ, Nakashima S (2009a) Electrical impedance measurement of hydrous microcrystalline quartz. J Mineral Petrol Sci 104:176-181. https://doi.org/10.2465/jmps.081022f

Fukuda J, Yokoyama T, Kirino Y (2009b) Characterization of the states and diffusivity of intergranular water in a chalcedonic quartz by high-temperature in situ infrared spectroscopy. Mineral Mag 73:825-835. https://doi. org/10.1180/minmag.2009.073.5.825

Fukuda J, Okudaira T, Satsukawa T, Michibayashi K (2012) Solution-precipitation of K-feldspar in deformed granitoids and its relationship to the distribution of water. Tectonophysics 532-535:175-185. https://doi.org/10.1016/j. tecto.2012.01.033

Fukuda J, Holyoke CW III, Kronenberg AK (2018) Deformation of fine-grained quartz aggregates by mixed diffusion and dislocation creep. J Geophys Res 123:4676-4696. https://doi.org/10.1029/2017JB015133

Fukuda J, Raimbourg H, Shimizu I, Neufeld K, Stünitz H (2019) Experimental grain growth of quartz aggregates under wet conditions and its application to deformation in nature. Solid Earth 10:621-636. https://doi. org/10.5194/se-10-621-2019

Gleason GC, DeSisto S (2008) A natural example of crystal-plastic deformation enhancing the incorporation of water into quartz. Tectonophysics 446:16-30. https://doi.org/10.1016/j.tecto.2007.09.006

Graetsch H, Flörke OW, Miehe G (1985) The nature of water in chalcedony and opal-C from Brazilian agate geodes. Phys Chem Miner 12:300-306. https ://doi.org/10.1007/BF00310343

Griggs DT (1967) Hydrolytic weakening of quartz and other silicates. Geophys J Int 14:19-31. https://doi.org/10.1111/j.1365-246X.1967.tb06218.x

Griggs DT, Blacic JD (1965) Quartz: anomalous weakness of synthetic crystals. Science 147:292-295. https://doi.org/10.1126/science.147.3655.292

Hara I, Shiota T, Takeda K, Hide K (1988) Tectonics of the Sambagawa belt. Chikyu Monthly 10:372-378 (in Japanese)

Hara I, Shiota T, Hide K, Goto M, Seki S, Kaikiri K, Takeda K, Hayasaka Y, Miyamoto T, Sakurai Y, Ohtomo Y (1992) Tectonic evolution of the Sambagawa schists and its implications in convergent margin processes. J Sci Hiroshima Univ Ser C 9:495

Higashino T (1990) The higher grade metamorphic zonation of the Sambagawa metamorphic belt in central Shikoku, Japan. J Metamorph Geol 8:413-423. https://doi.org/10.1111/j.1525-1314.1990.tb00628.x

Hiraga T, Nagase T, Akizuki M (1999) The structure of grain boundaries in granite-origin ultramylonite studied by high-resolution electron microscopy. Phys Chem Miner 26:617-623. https://doi.org/10.1007/s002690050226

Hiraga T, Nishikawa O, Nagase T, Akizuki M (2001) Morphology of intergranular pores and wetting angles in pelitic schists studied by transmission electron microscopy. Contrib Mineral Petrol 141:613-622. https://doi. org/10.1007/s004100100263

Hiraga T, Watanabe Y, Miyazaki T (2012) Observation of intergranular fluids. Chikyukagaku 46:231-242. https://doi.org/10.14934/chikyukagaku.46.231 (in Japanese with English abstract)

Hirth G, Tullis J (1992) Dislocation creep regimes in quartz aggregates. J Struct Geol 14:145-159. https://doi.org/10.1016/0191-8141(92)90053-Y

Holyoke CW III, Kronenberg AK (2013) Reversible water weakening of quartz. Earth Planet Sci Lett 374:385-390. https://doi.org/10.1016/j. epsl.2013.05.039

Itaya T (1981) Carbonaceous material in pelitic schists of the Sanbagawa metamorphic melt in central Shikoku, Japan. Lithos 14:215-224. https:// doi.org/10.1016/0024-4937(81)90043-8

Ito Y, Nakashima S (2002) Water distribution in low-grade siliceous metamorphic rocks by micro-FTIR and its relation to grain size: a case from the Kanto Mountain region, Japan. Chem Geol 189:1-18. https://doi. org/10.1016/S0009-2541(02)00022-0

Jaoul O, Tullis J, Kronenberg A (1984) The effect of varying water contents on the creep behavior of Heavitree quartzite. J Geophys Res 89:4298-4312. https://doi.org/10.1029/JB089iB06p04298

Kats A (1962) Hydrogen in alpha quartz. Philips Res Rep 17(133-195):201-279

Kilian R, Heilbronner R, Holyoke CW III, Kronenberg AK, Stünitz H (2016) Dislocation creep of dry quartz. J Geophys Res 121:3278-3299. https://doi. org/10.1002/2015JB012771 
Koch PS, Christie JM, Ord A, George RP Jr (1989) Effect of water on the rheology of experimentally deformed quartzite. J Geophys Res 94:1397513996. https://doi.org/10.1029/JB094iB10p13975

Kronenberg AK (1994) Hydrogen speciation and chemical weakening of quartz. Rev Mineral Geochem 29:123-176

Kronenberg AK, Tullis J (1984) Flow strengths of quartz aggregates: grain size and pressure effects due to hydrolytic weakening. J Geophys Res 89:4281-4297. https://doi.org/10.1029/JB089iB06p04281

Kronenberg AK, Wolf GH (1990) Fourier transform infrared spectroscopy determinations of intragranular water content in quartz-bearing rocks: implications for hydrolytic weakening in the laboratory and within the earth. Tectonophysics 172:225-271. https://doi.org/10.1016/00401951(90)90034-6

Kronenberg AK, Segall P, Wolf GH (1990) Hydrolytic weakening and penetrative deformation within a natural shear zone. In: Duba AG, Durham WB, Handin JW, Wang HF (eds) The Brittle-Ductile transition in rocks. American Geophysical Union, Washington DC, pp 21-36. https://doi.org/10.1029/ GM056p0021

Kronenberg AK, Hasnan HFB, Holyoke CW III, Law RD, Liu Z, Thomas JB (2017) Synchrotron FTIR imaging of $\mathrm{OH}$ in quartz mylonites. Solid Earth 8:1025-1045. https://doi.org/10.5194/se-8-1025-2017

Libowitzky E, Rossman GR (1997) An IR absorption calibration for water in minerals. Am Mineral 82:1111-1115. https://doi.org/10.2138/ am-1997-11-1208

Lister GS (1977) Crossed-girdle c-axis fabrics in quartzites plastically deformed by plane strain and progressive simple shear. Tectonophysics 39:51-54. https://doi.org/10.1016/0040-1951(77)90087-7

Masuda T (1982) A microstructural sequence of quartz schists in central Shikoku, south-west, Japan. Tectonophysics 83:329-345. https://doi. org/10.1016/0040-1951(82)90026-9

Masuda T, Fujimura A (1981) Microstructural development of fine-grained quartz aggregates by syntectonic recrystallization. Tectonophysics 72:105-128. https://doi.org/10.1016/0040-1951(81)90089-5

Menegon L, Nasipuri P, Stünitz H, Behrens H, Ravna E (2011) Dry and strong quartz during deformation of the lower crust in the presence of melt. J Geophys Res 116:B10410. https://doi.org/10.1029/2011JB008371

Muto J, Nagahama H, Hashimoto T (2004) Micro-infrared reflection spectroscopic mapping: application to the detection of hydrogen-related species in natural quartz. J Microsc 216:222-228. https://doi.org/10.111 1/j.0022-2720.2004.01419.x

Muto J, Nagahama H, Hashimoto T (2005) Water distribution in dynamically recrystallized quartz grains: cathodoluminescence and micro-infrared spectroscopic mapping. In: Bruhn D, Durlini L (eds) High-strain zones: Structure and physical properties, vol 245. Geol Soc London Spec Publ, London, pp 397-407. https://doi.org/10.1144/GSL.SP.2005.245.01.19

Nakashima S, Matayoshi H, Yuko T, Michibayashi K, Masuda T, Kuroki N, Yamagishi H, Ito Y, Nakamura A (1995) Infrared microspectroscopy analysis of water distribution in deformed and metamorphosed rocks. Tectonophysics 245:263-276. https://doi.org/10.1016/0040-1951(94)00239-6

Niimi N, Aikawa N, Shinoda K (1999) The infrared absorption band at $3596 \mathrm{~cm}^{-1}$ of the recrystallized quartz from Mt. Takamiyama, southwest Japan. Mineral Mag 63:693-701. https://doi.org/10.1180/0026461995 48853

Oinuma K, Hayashi H (1965) Infrared study of mixed-layer clay minerals. Am Mineral 50:1213-1227

Parrish DK, Krivz AL, Carter NL (1976) Finite-element folds of similar geometry. Tectonophysics 32:183-207. https://doi.org/10.1016/0040-1951(76)90062 $-7$

Paterson MS (1982) The determination of hydroxyl by infrared absorption in quartz, silicate glasses and similar materials. Bull Minéral 105:20-29

Paterson MS (1986) The thermodynamics of water in quartz. Phys Chem Miner 13:245-255. https://doi.org/10.1007/BF00308276
Post A, Tullis J, Yund RA (1996) Effects of chemical environment on dislocation creep of quartzite. J Geophys Res 101:22143-22155. https://doi. org/10.1029/96JB01926

Prieto AC, Dubessy J, Cathelineau M (1991) Structure-composition relationships in trioctahedral chlorites: a vibrational spectroscopy study. Clays Clay Miner 39:531-539. https://doi.org/10.1346/ccmn.1991.0390508

Shimizu I (1988) Ductile deformation in the low-grade part of the Sambagawa metamorphic belts in the northern Kanto Mountains, Central Japan. J Geol Soc Japan 94:609-628. https://doi.org/10.5575/geosoc.94.609

Shimizu I (1998) Lognormality in crystal size distribution during dynamic recrystallization. FORMA 13:1-11

Shimizu I (1999) A stochastic model of grain size distribution during dynamic recrystallization. Philos Mag A 79:1217-1231. https://doi. org/10.1080/01418619908210357

Shimizu I (2008) Theories and applicability of grain size piezometers: the role of dynamic recrystallization mechanisms. J Struct Geol 30:899-917. https ://doi.org/10.1016/j.jsg.2008.03.004

Shimizu I (2011) Erratum to "Theories and applicability of grain size piezometers: the role of dynamic recrystallization mechanisms" [J Struct Geol 30 (2008) 899-917]. J Struct Geol 33:1136-1137. https://doi.org/10.1016/j. jsg.2011.03.011

Shimizu I (2012) Steady-state grain size in dynamic recrystallization of minerals. In: Sztwiertnia K (ed) Recrystallization. InTech, Rijeka, pp 371-386. https:// doi.org/10.5772/33701

Stalder R, Konzett J (2012) OH defects in quartz in the system quartz-albitewater and granite-water between 5 and 25 kbar. Phys Chem Miner 39:817-827. https://doi.org/10.1007/s00269-012-0537-5

Stipp M, Tullis J, Behrens H (2006) Effect of water on the dislocation creep microstructure and flow stress of quartz and implications for the recrystallized grain size piezometer. J Geophys Res 111:B04201. https://doi. org/10.1029/2005JB003852

Stünitz H, Thust A, Heilbronner R, Behrens H, Kilian R, Tarantola A, Fitz Gerald JD (2017) Water redistribution in experimentally deformed natural milky quartz single crystals_-implications for $\mathrm{H}_{2} \mathrm{O}$-weakening processes. J Geophys Res 122:866-894. https://doi.org/10.1002/2016JB013533

Tagami M, Takeshita T (1998) C-Axis fabrics and microstructures in quartz schist from the Sambagawa metamorphic belt, central Shikoku, Japan. J Struct Geol 20:1549-1568. https://doi.org/10.1016/S0191-8141(98)00044-3

Takahashi M, Nagahama H, Masuda T, Fujimura A (1998) Fractal analysis of experimentally, dynamically recrystallized quartz grains and its possible application as a strain rate meter. J Struct Geol 20:269-275. https://doi. org/10.1016/S0191-8141(97)00072-2

Thomas SM, Koch-Müller M, Reichart P, Rhede D, Thomas R, Wirth R, Matsyuk $S$ (2009) IR calibrations for water determination in olivine, $r-\mathrm{GeO}_{2}$, and $\mathrm{SiO}_{2}$ polymorphs. Phys Chem Miner 36:489-509. https://doi.org/10.1007/ s00269-009-0295-1

Thompson WK (1965) Infra-red spectroscopic studies of aqueous systems. Part 1. Molar extinction coefficients of water, deuterium oxide, deuterium hydrogen oxide, aqueous sodium chloride and carbon disulphide. Trans Faraday Soc 61:2635-2640. https://doi.org/10.1039/TF9656102635

Yagi K, Takeshita T (2002) Regional variation in exhumation and strain rate of the high-pressure Sambagawa metamorphic rocks in central Shikoku, south-west Japan. J Metamorph Geol 20:633-647. https://doi.org/10.104 6/j.1525-1314.2002.00392.x

\section{Publisher's Note}

Springer Nature remains neutral with regard to jurisdictional claims in published maps and institutional affiliations. 